\title{
Konrad Marciniuk
}

Uniwersytet Warszawski

k.marciniuk@wpia.uw.edu.pl

\section{Dziedziczenie gospodarstw rolnych a zmiany w ustawie o kształtowaniu ustroju rolnego dokonane w kwietniu 2016 r.}

\author{
Inheritance of Farms in Light of Changes in the Act on Structuring \\ of the Agrarian System
}

\begin{abstract}
The article discusses the impact of recent changes in the Act on Structuring of the Agrarian System (ustawa o kształtowaniu ustroju rolnego) on the rules governing inheritance of agricultural farms. The article presents the evolution of the Polish regulation with respect to the general mortis causa legal succession of farms, particularly in the process of political and economic changes that have taken place in Poland during the past 25 years. Much attention is paid to the constitutionality of legal intervention in the common order of inheritance of agricultural holdings. In particular the article discusses the ruling of the Constitutional Tribunal of 31 January 2001, which sits at the forefront of further development in the shaping of rules governing the inheritance of farms. Detailed analysis of the current regulation brought about by the recent changes to the Act on Structuring of the Agrarian System, leads to the conclusion that complex regulation on the inheritance of farms as a means of ensuring efficient protection of their economic integrity in the process of succession, remains open.
\end{abstract}

Keywords: agriculture, farm land, farms, inheritance, structuring of the agrarian system

Słowa kluczowe: rolnictwo, nieruchomość rolna, gospodarstwo rolne, dziedziczenie gospodarstw rolnych, kształtowanie ustroju rolnego

\section{Wstęp}

W wyniku wejścia w życie ustawy z dnia 14 kwietnia 2016 r. o wstrzymaniu sprzedaży nieruchomości Zasobu Własności Rolnej Skarbu Państwa oraz o zmianie niektórych ustaw ${ }^{1}$ istotnym zmianom uległy obowiązujące dotąd zasady obrotu nie-

Dz.U. poz. 585 ze zm. 
ruchomościami rolnymi. Choć niewątpliwie głównym przedmiotem zainteresowania ustawodawcy był obrót inter vivos, to w konsekwencji zmian, jakie na podstawie tej ustawy zostały wprowadzone w ustawie z dnia 11 kwietnia 2003 r. o kształtowaniu ustroju rolnego ${ }^{2}$, modyfikacji uległy także uwarunkowania prawne dziedziczenia gospodarstw rolnych. Samo podjęcie przez ustawodawcę zagadnienia regulacji losów gospodarstwa rolnego na wypadek śmierci rolnika należałoby przyjąć z uznaniem, gdyby zmiany te rzeczywiście kreowały spójny system podporządkowany realizacji celów deklarowanych przez ustawodawcę, uwzględniający przy tym dyrektywy sformułowane przez Trybunał Konstytucyjny w uzasadnieniu wyroku z dnia 31 stycznia 2003 r. ${ }^{3}$ Tymczasem, jak się wydaje, objęcie niektórych aspektów dziedziczenia gospodarstw rolnych reglamentacją prawną wynikającą z ostatnich zmian w u.k.u.r. jest raczej wynikiem przypadku i jako takie nie będzie miało większego znaczenia z punktu widzenia pozytywnego oddziaływania na kształtowanie się struktury rolnej w Polsce. Należy to przyjąć z żalem - można byłoby bowiem oczekiwać, że dokonując gruntownej nowelizacji ustawy o kształtowaniu ustroju rolnego $w$ trosce o - jak sam ustawodawca ujął to w preambule dodanej do zmienianej u.k.u.r. - „wzmocnienie ochrony i rozwoju gospodarstw rodzinnych” oraz o „zapewnienie właściwego zagospodarowania ziemi rolnej w Rzeczypospolitej Polskiej", ustawodawca podejmie wysiłek w kierunku objęcia efektywną ochroną gospodarstw rodzinnych także $\mathrm{w}$ procesie dziedziczenia, czego jednak nie uczynił. Naturalną konsekwencją objęcia zarówno obrotu nieruchomościami rolnymi, jak i gospodarstwami rolnymi inter vivos szczegółową reglamentacją prawną powinno być bowiem jednoczesne objęcie tych gospodarstw ochroną $w$ procesie dziedziczenia, co jest rozwiązaniem szeroko stosowanym w praktycznie wszystkich państwach Europy Zachodniej ${ }^{4}$.

\section{Ewolucja regulacji dotyczących szczególnych zasad dziedziczenia gospodarstw rolnych}

Problematyka dziedziczenia gospodarstw rolnych jest przedmiotem szczególnego zainteresowania ustawodawcy od bardzo dawna. Już na wstępie należy jednak zauważyć, że na przestrzeni lat zmianom ulegały zarówno cele, jakie ustawodawca starał się osiągać poprzez ingerencję w porządek dziedziczenia gospodarstw rolnych, jak i intensywność tej ingerencji. Nierzadko też przepisy dotyczące dziedziczenia gospodarstw rolnych służyły realizacji celów zgoła innych niż deklarowane. Przykładowo, w latach 60. zawężono, w porównaniu z zasadami ogólnymi, krąg spadkobierców

2 Tekst jedn. Dz.U. z 2016 r. poz. 2052 ze zm., dalej: u.k.u.r.

3 Wyrok Trybunału Konstytucyjnego z dnia 31 stycznia 2001 r., P 4/99, OTK 2001, nr 1, poz. 5.

4 Patrz szerzej A. Lichorowicz, Podstawowe rozwiązania regulujące status prawny gospodarstw rodzinnych w krajach Europy Zachodniej, (w:) P. Litwiniuk (red.), Prawne mechanizmy wspierania i ochrony rolnictwa rodzinnego w Polsce i innych państwach Unii Europejskiej, Warszawa 2015. 
ustawowych rolnika, jak też sformułowano wymóg spełniania przez nich surowych przesłanek produkcyjnych do tego stopnia, że uzasadniona wydaje się teza, iż szczególne zasady dziedziczenia stały się jednym z instrumentów realizowanej w tamtym okresie polityki kolektywizacyjnej. W konsekwencji, przyjęte wówczas rozwiązania szczegółowe znacząco odbiegały od głównego celu ingerowania w kwestie następstwa w gospodarstwach rolnych, jakim niewątpliwie powinna być ochrona gospodarstwa rolnego jako warsztatu pracy rolnika oraz dążenie do poprawy, a przynajmniej ochrony struktury agrarnej. Przepisy te ulegały jednak stopniowej ewolucji. Zmieniał się także kontekst społeczno-polityczny, w którym przepisy te funkcjonowały.

Systematyzując proces kształtowania się współczesnej regulacji dotyczącej dziedziczenia gospodarstw rolnych należy zwrócić uwagę, że pierwszym powojennym aktem prawnym regulującym to zagadnienie był dekret z dnia 8 października $1946 \mathrm{r}$. o prawie spadkowym 5 . Dekret ten wprawdzie nie zawierał szczególnych przepisów dotyczących dziedziczenia po osobie prowadzącej gospodarstwo rolne, niemniej jednak art. $60 \$ 2$, tego dekretu poprzez odesłanie do art. $95 \$ 2$ dekretu o prawie rzeczowym $^{6}$, a więc rozszerzając jego stosowanie także do działu spadku, de facto ustanawiał zakaz dokonywania podziału nieruchomości rolnej w razie sprzeczności tego podziału $\mathrm{z}$ interesem społeczno-gospodarczym ${ }^{7}$.

Z kolei przepisy art. $147 \$ 1$ i art. $152 \$ 3$ dekretu z dnia 8 listopada 1946 r. o postępowaniu spadkowym ${ }^{8}$ uzależniały dopuszczalność podziału nieruchomości od jego zgodności z interesem społeczno-gospodarczym, natomiast przepisy art. 162 $\$ 1$ i 2 tego dekretu określały, któremu spadkobiercy należy przyznać nieruchomość w przypadku niemożności jej podziału. W związku z ww. aktami prawnymi, Sąd Naj-

$5 \quad$ Dz.U. Nr 60, poz. 328.

6 Dekret z dnia 11 października 1946 r. - Prawo rzeczowe (Dz.U. z 1946 r. poz. 319).

7 W wyroku Sądu Wojewódzkiego w Poznaniu z dnia 20 grudnia 1960 r. (III Cr 1049/60, Lex $\mathrm{nr} 1724319)$ sąd stwierdzil, że wynikający z art. $95 \$ 2$ prawa rzeczowego i art. $60 \$ 2$ prawa spadkowego zakaz podziału nieruchomości niezgodnego $\mathrm{z}$ interesem społeczno-gospodarczym obowiązuje nie tylko sądy, które przeprowadzają postępowanie o zniesienie współwłasności nieruchomości lub o podział spadku obejmującego nieruchomość, lecz również państwowe biura notarialne, w których sporządza się umowy o zniesienie współwłasności nieruchomości lub o podział spadku obejmującego nieruchomość. Sporządzona wbrew temu zakazowi umowa o zniesienie współwłasności nieruchomości lub o podział spadku obejmującego nieruchomość jest nieważna z mocy art. $41 \$ 1$ przep. og. pr. cyw. Dlatego państwowe biuro notarialne, mając sporządzić taką umowę, winno upewnić się, że dokonany w niej podział nieruchomości nie będzie niezgodny z interesem społeczno-gospodarczym. Również sąd prowadzący księgi wieczyste musi dojść do takiego przekonania, gdy na podstawie tej umowy ma dokonać wpisu w księdze wieczystej. Co więcej, sąd wyraził opinię, że gdy przedmiotem podziału ma być nieruchomość rolna, to zarówno państwowe biuro notarialne, jak i sąd prowadzący księgi wieczyste mogą oprzeć swoje przekonanie o tym, że jej podział nie będzie niezgodny z interesem społeczno-gospodarczym, jedynie na opinii organu administracji rolnej, wyrażonej w urzędowym zaświadczeniu tego organu. 
wyższy w uchwale z dnia 22 lutego 1960 r. ${ }^{9}$ określił minimalny obszar, który powinien być przestrzegany przy dziale spadku oraz zalecił przyznanie gospodarstwa rolnego temu spadkobiercy, który gwarantuje należytą produkcyjność tego gospodarstwa.

Kolejnym etapem rozwoju regulacji dotyczących dziedziczenia gospodarstw rolnych w Polsce była ustawa z dnia 29 czerwca 1963 r. o ograniczeniu podziału gospodarstw rolnych ${ }^{10}$. Ustawa ta była pierwszym aktem prawnym wyraźnie ukierunkowanym na kształtowanie struktury agrarnej państwa poprzez długofalowe oddziaływania na obrót ziemią, w tym kształtowanie stosunków w zakresie obrotu ziemią na wypadek śmierci. Deklarowane przez ówczesnego ustawodawcę zasadnicze założenia tej ustawy zmierzały do zapewnienia, aby ziemia pozostawała w rękach pracujących rolników, mających odpowiednie kwalifikacje do prowadzenia gospodarstwa rolnego, a także do ochrony tego gospodarstwa jako warsztatu pracy ${ }^{11}$. W rzeczywistości jednak regulacja ta umożliwiła przechodzenie ziemi na własność państwa w wyniku działania przepisów prawa spadkowego ${ }^{12}$. W ustawie tej sformułowano przesłanki, od spełnienia których uzależnione było dziedziczenie gospodarstwa rolnego przez spadkobierców. Natomiast w przypadku braku ich spełnienia, gospodarstwo rolne przypadało państwu jako spadkobiercy ustawowemu. Powyższe przepisy zostały następnie włączone do Kodeksu cywilnego ${ }^{13}$ i zamieszczone w jego księdze IV zatytułowanej „Przepisy szczególne o dziedziczeniu gospodarstw rolnych”. Jednocześnie, z jednej strony poszerzono krąg spadkobierców mogących dziedziczyć gospodarstwo rolne (stawiając wobec nich wymóg spełniania odrębnych wymagań, określonych w art. $1060 \$ 2$ i art. $1062 \$ 2$ kc.), z drugiej zaś wyłączono z tego kręgu spadkobierców dalszych niż wnuki i zstępni rodzeństwa. Jak się podkreśla, taka regulacja rozszerzyła możliwości nabywania gospodarstw rolnych przez Skarb Państwa ${ }^{14}$. Regulacja ta stanowiła apogeum stopnia ingerencji w porządek dziedziczenia gospodarstw rolnych.

Jak zauważa A. Lichorowicz ${ }^{15}$, w trakcie każdej odwilży politycznej w Polsce, jakie następowały po 1964 r., podnoszono żądania złagodzenia zasad dziedziczenia gospodarstw rolnych, $\mathrm{z}$ reguły uwieńczone sukcesem. W efekcie, $\mathrm{z}$ biegiem czasu, wraz z kolejnymi nowelizacjami kodeksu cywilnego, przepisy dotyczące dziedziczenia gospodarstw rolnych ulegały stopniowej liberalizacji.

9 I Co 34/59, OSN CK 1960, nr 2, poz. 31.

10 Dz.U. Nr 28, poz. 168.

11 A. Stelmachowski, B. Zdziennicki, Prawo rolne, Warszawa 1980, s. 280.

12 Uzasadnienie wyroku TK z dnia 31 stycznia 2001 r., P 4/99, op. cit.

13 Ustawa z dnia 23 kwietnia 1964 r. - Kodeks cywilny (tekst jedn. Dz.U. z 2017 r. poz. 459 ze zm.), dalej: kc.

14 Uzasadnienie wyroku TK z dnia 31 stycznia 2001 r., P 4/99, op. cit.

15 A. Lichorowicz, Szczególny porządek dziedziczenia gospodarstw rolnych w Polsce po orzeczeniu Trybunału Konstytucyjnego z dnia 31 I 2001 r., „Rejent” 2001, nr 9(125), s. 89. 
Dziedziczenie gospodarstw rolnych a zmiany w ustawie o kształtowaniu ustroju...

Ustawa z 1971 r. zmieniająca ustawę - Kodeks cywilny ${ }^{16}$ wprowadziła zmiany w przesłankach dziedziczenia gospodarstwa rolnego polegające przede wszystkim na rozszerzeniu kręgu spadkobierców ustawowych o dzieci rodzeństwa spadkodawcy. Dopuszczona została wówczas również możliwość przyznania gospodarstwa rolnego spadkobiercy, który był trwale niezdolny do pracy, jednak mógł prowadzić takie gospodarstwo przy pomocy osoby bliskiej. W regulacji z 1971 r. zrezygnowano także z obowiązującego wcześniej wymogu wykazywania przez spadkobiercę spełniania przesłanki obejmującej roczną nieprzerwaną pracę w gospodarstwie spadkowym. Powyższa regulacja ograniczyła tym samym możliwość dziedziczenia gospodarstw rolnych przez państwo ${ }^{17}$.

Dalsze istotne zmiany w regulacji dziedziczenia gospodarstw rolnych wprowadzono na mocy ustawy z dnia 26 marca 1982 r. o zmianie ustawy - Kodeks cywilny oraz o uchyleniu ustawy o uregulowaniu własności gospodarstw rolnych ${ }^{18}$. Przede wszystkim do dziedziczenia gospodarstwa rolnego zostały dopuszczone wówczas osoby należące według zasad ogólnych do kręgu spadkobierców ustawowych (tj. wszyscy wstępni i zstępni rodzeństwa), pod warunkiem spełnienia przesłanek określonych w art. 1059, 1060 i 1062 kc. Zmianie uległa również sama regulacja przesłanek dziedziczenia gospodarstwa rolnego. Zostały one ujęte w sposób ogólny, taki sam dla wszystkich spadkobierców, co stanowiło regulację odmienną od dotychczasowego ujmowania ich w sposób wysoce kazuistyczny ${ }^{19}$. Tym samym ujednolicono tzw. przesłanki produkcyjne dziedziczenia z przesłankami warunkującymi możliwość nabycia własności nieruchomości rolnej w obrocie inter vivos ${ }^{20}$. Jednocześnie, jak wynika z treści art. 1063 kc. w brzmieniu ustalonym ww. ustawą, „jeżeli żaden ze spadkobierców ustawowych nie odpowiadał warunkom przewidzianym dla dziedziczenia gospodarstwa rolnego albo jeżeli uprawnionym do dziedziczenia były wyłącznie osoby, które w chwili otwarcia spadku były trwale niezdolne do pracy, wówczas gospodarstwo rolne dziedziczyli spadkobiercy na zasadach ogólnych". A zatem, co wydaje się najistotniejsze, zerwano wówczas z dotychczasowym modelem dziedziczenia gospodarstwa przez państwo w razie braku możliwości dziedziczenia przez uprawnionych spadkobierców ${ }^{21}$. Zmianom uległo również ustawowe prawo pierwokupu przysługujące Skarbowi Państwa w trakcie działu spadku oraz zmieniona została maksymalna norma obszarowa wyznaczająca górny pułap nabycia własności rolnej przez dziedziczenie. Natomiast 5-letni zakaz zbywania gospodarstwa rolnego

\footnotetext{
16 Dz.U. Nr 27, poz. 252.

17 A. Lichorowicz, Szczególny porządek..., op. cit., s. 89.

18 Dz.U. Nr 55, poz. 81.

19 Wyrok TK z dnia 31 stycznia 2001 r., P 4/99, op. cit.

20 A. Lichorowicz, Szczególny porządek..., op. cit., s. 89.

21 Wyrok TK z dnia 31 stycznia 2001 r., P 4/99, op. cit.
} 
uzyskanego w wyniku działu spadku zastąpiono 10-letnim obowiązkiem wydania pozostałym spadkobiercom korzyści uzyskanych w wyniku jego zbycia ${ }^{22}$.

Kolejna istotna zmiana zasad rządzących dziedziczeniem gospodarstw rolnych wiązała się z nowelizacją kodeksu cywilnego dokonaną na podstawie ustawy z dnia 28 lipca 1990 r. o zmianie ustawy - Kodeks cywilny ${ }^{23}$. Zniesiono wówczas wymóg spełnienia szczególnych przesłanek dziedziczenia gospodarstwa rolnego przez spadkobierców dochodzących do spadkobrania na podstawie testamentu. Ograniczono też stosowanie przepisów szczególnych o dziedziczeniu gospodarstw rolnych tylko do gospodarstw obejmujących grunty rolne przekraczające 1 ha. Powyższa nowelizacja kodeksu cywilnego, wpisująca się zresztą w nurt bardzo liberalnych przemian gospodarczych początku lat 90. ubiegłego wieku, umożliwiła także zwrot rolnikom nieruchomości przejętych uprzednio przez Skarb Państwa w ramach dziedziczenia na podstawie art. $1063 \mathrm{kc}$., w jego poprzednim brzmieniu.

$\mathrm{Z}$ drugiej jednak strony utrzymano wówczas w mocy szczególne przesłanki ustawowego dziedziczenia gospodarstw rolnych. Doprowadziło to do paradoksalnej sytuacji, w której zarówno w ramach obrotu inter vivos, jak też w przypadku dziedziczenia testamentowego, nabywać gospodarstwo rolne bez jakichkolwiek ograniczeń i bez konieczności spełnienia jakichkolwiek wymagań mógł praktycznie każdy, podczas gdy w przypadku dziedziczenia ustawowego, spadkobierca nadal musiał spełniać rygorystyczne przesłanki wynikające przede wszystkim z art. 1059-1062 kc.

Proces zmian, a w zasadzie stopniowego demontażu modelu szczególnej ingerencji w proces dziedziczenia gospodarstw rolnych przypieczętował ostatecznie wyrok Trybunału Konstytucyjnego z dnia 31 stycznia 2001 r. ${ }^{24}$, w którym trybunał stwierdził niekonstytucyjność szczególnych wymogów stawianych spadkobiercom ustawowym gospodarstw rolnych przez przepisy tytułu X księgi IV kc. ${ }^{25} \mathrm{~W}$ szczególności trybunał uznał za sprzeczne z Konstytucją ${ }^{26}$ przepisy art. 1059, 1060, 1062, 1063 i 1087 kc. określające wymagania stawiane wobec spadkobierców ustawowych spadku w części obejmującej gospodarstwo rolne lub wkład gruntowy do rolniczej spółdzielni produkcyjnej.

Zauważyć należy, że liczne, zmierzające w kierunku liberalizacji, zmiany przepisów dotyczących dziedziczenia gospodarstw rolnych nie oznaczają wcale, że porzucono ideę samodzielnego (odrębnego) uregulowania problematyki masy spadkowej, w skład której wchodzi gospodarstwo rolne lub wkład gruntowy w rolniczej spółdzielni produkcyjnej.

22 A. Lichorowicz, Szczególny porządek..., op. cit., s. 90.

23 Dz.U. Nr 55, poz. 321.

24 P 4/99, op. cit.

25 A. Lichorowicz, Szczególny porządek..., op. cit., s. 91-92.

26 Konstytucja Rzeczypospolitej Polskiej z dnia 2 kwietnia 1997 r. (Dz.U. Nr 78, poz. 483 ze zm.), dalej: Konstytucja. 
Ostateczne wyeliminowanie z kodeksu cywilnego większości przepisów dotyczących szczególnych zasad dziedziczenia gospodarstw rolnych nie oznacza także, że obowiązujące wcześniej przepisy utraciły jakiekolwiek znaczenie. Należy bowiem zwrócić uwagę, na jednoczesny proces ewolucji norm określających zakres czasowy obowiązywania przepisów szczególnych dotyczących dziedziczenia gospodarstw rolnych. W szczególności wskazać należy przykładowo, że do 1982 r. szereg przyjmowanych regulacji dotyczących problematyki dziedziczenia gospodarstw rolnych działało wstecz, mając zastosowanie do spadków otwartych przed ich wejściem w ży$\mathrm{cie}^{27}$. Konsekwencją takich uregulowań obecnie jest stosowanie przepisów o dziedziczeniu gospodarstw rolnych w kilku różnych ujęciach, w zależności od tego, kiedy nastąpiło otwarcie spadku ${ }^{28}$.

Także w przywołanym wyroku Trybunał Konstytucyjny, uznając, że porządek prawny dziedziczenia gospodarstw rolnych jest determinowany datą otwarcia spadku, która ma wpływ zarówno na krąg spadkobierców, jak i na przesłanki umożliwiające dziedziczenie, wskazał, iż utrata mocy obowiązującej przez szczególne przepisy o dziedziczeniu gospodarstw rolnych następuje ex nunc. Swoje stanowisko trybunał uzasadnił przede wszystkim szeroko rozumianą zasadą lex retro non agit, jako zasadą koncepcji państwa prawnego oraz zasadą pewności obrotu. Niewątpliwie przyjęte przez trybunał rozwiązanie charakteryzuje się wysokim stopniem pragmatyzmu i świadczy o świadomości ewentualnych ogromnych skutków przyjęcia rozwiązania odmiennego ${ }^{29}$.

\section{Kwestia szczególnych zasad dziedziczenia gospodarstw rolnych w świetle Konstytucji}

Uzasadniając wyrok z dnia 31 stycznia 2001 roku, Trybunał Konstytucyjny wyjaśnił, że art. 64 ust. 1 Konstytucji potwierdza przysługujące każdemu „prawo dziedziczenia", które należy do konstytucyjnych praw podmiotowych o charakterze

27 Cechą charakterystyczną ustawy z 1963 r., która weszła w życie dnia 5 lipca 1963 r., było nadanie jej w szerokim zakresie mocy wstecznej. Zgodnie bowiem $\mathrm{z}$ art. 24 ust. 1 ww. ustawy, jej przepisy miały zastosowanie także do spadków otwartych przed dniem wejścia w życie tej ustawy, o ile dalsze przepisy (art. 24 ust. 2-8) nie stanowiły inaczej. Z kolei sformułowane w kodeksie cywilnym przepisy szczególne dotyczące dziedziczenia gospodarstw rolnych weszły w życie już z dniem jego ogłoszenia, tj. 18 maja 1964 r., podczas gdy sam kodeks wszedł w życie dopiero 1 stycznia 1965 r. Jednocześnie, na mocy przepisów wprowadzających kodeks cywilny, przepisom art. 1058-1088 kc. nadano moc wsteczną. Moc wsteczną nadano także wspomnianej wcześniej nowelizacji przepisów kodeksu cywilnego z 1971 r., choć nie dotyczyło to przypadków, w których przed dniem 5 lipca 1963 r. dokonany już został dział spadku. Natomiast do spadków otwartych po 1963 r. zastosowanie miały reguły wynikające z przepisów wprowadzających kodeks cywilny.

28 Wyrok TK z dnia 31 stycznia 2001 r., P 4/99, op. cit.

29 A. Lichorowicz, Szczególny porządek..., op. cit., s. 92-94. 
powszechnym. Trybunał wskazał nadto, że w myśl art. 21 ust. 1 Konstytucji, Rzeczpospolita Polska chroni własność i prawo dziedziczenia. Natomiast art. 20 Konstytucji uznaje własność prywatną za jedną z podstaw społecznej gospodarki rynkowej, będącej podstawą ustroju gospodarczego RP.

W dalszej części uzasadnienia przywołanego wyroku, trybunał, odnosząc się do znaczenia art. 64 ust. 1 Konstytucji wskazał, że stanowi on podstawę publicznego prawa podmiotowego, którego treścią jest gwarantowana konstytucyjnie wolność nabywania mienia, jego zachowania i dysponowania nim (czyli dokonywania przez uprawnionego czynności inter vivos $i$ mortis causa). Natomiast zestawienie norm wynikających z treści art. 64 oraz art. 21 ust. 1 Konstytucji pozwala wysnuć wniosek, że: „Konstytucja wyłącza możliwość pozbawienia własności, będącej najpełniejszym z praw majątkowych, cechy dziedziczności”. Trybunał wyraził również pogląd, że samo pojęcie dziedziczenia, rozumiane na tle przepisów konstytucyjnych, winno być rozumiane szerzej, niż ma to miejsce w przypadku księgi IV kc., w której pojęcie to odnoszone jest jedynie do samego sposobu dziedziczenia, tj. przejścia praw i obowiązków majątkowych przysługujących osobie fizycznej aż do śmierci na inną osobę. Zdaniem trybunału natomiast, z punktu widzenia art. 20 i 21 Konstytucji, prawo dziedziczenia jest gwarancją pozostawania własności w rękach prywatnych, co w związku z art. 64 ust. 1 i 2 Konstytucji stanowi obowiązek skierowany do ustawodawcy, nakazujący objęcie regulacją ustawową problematyki wynikającej ze śmierci osoby fizycznej. Trybunał podkreślił przy tym, że dziedziczenie stanowi utrwalenie prawa własności, które polega na tym, iż prawo to przysługuje osobie fizycznej i nie może wygasać w chwili jej śmierci, ale powinno trwać nadal, co zakłada jego przejście na inną osobę lub osoby. Konstytucyjna gwarancja prawa dziedziczenia ma - zdaniem Trybunału - znaczenie „negatywne”, ustanawia bowiem zakaz arbitralnego przejmowania przez państwo własności osób zmarłych. Innymi słowy, brak jest możliwości „ukrytego” wywłaszczania poprzez pozbawienie składników majątkowych osób zmarłych statusu własności prywatnej. Istota prawa dziedziczenia czyni własność prywatną instytucją trwałą, która nie jest ograniczona czasowo, nie zależy od długości życia, której w danym momencie przysługują uprawnienia właścicielskie.

Trybunał zaznaczył jednak również, że nie jest zupełnie wykluczone przejście własności osoby zmarłej na rzecz Skarbu Państwa, lecz może mieć to miejsce dopiero wówczas, gdy nie ma możliwości ustalenia następców prawnych spadkodawcy. Zdaniem trybunału, zakres swobody ustawodawcy przy realizacji wynikającego z Konstytucji nakazu uregulowania dziedziczenia ustawowego dopuszcza dalej idącą, niż w przypadku dziedziczenia opartego na woli spadkodawcy, ingerencję co do reżimu prawnego poszczególnych składników majątku zmarłego, bowiem swoboda testowania obejmuje prawo decydowania nie tylko o dalszych losach majątku jako całości, ale także o różnym przeznaczeniu poszczególnych jego składników. W związku z tym ustawodawcy, który działa niejako w zastępstwie spadkodawcy, nie można takiego rozwiązania całkowicie zabronić. 
Ponadto trybunał wskazał, że z art. 64 Konstytucji wynika zakaz pozbawiania jakiejś kategorii osób zdolności dziedziczenia po śmierci osoby, której przysługiwały one za życia. A zatem przepis ten zapewnia każdemu samą możliwość stania się następcą prawnym osoby zmarłej, jednak nie przesądza on o porządku dziedziczenia, jak też nie gwarantuje nikomu uzyskania praw majątkowych w drodze dziedziczenia. W konsekwencji należy uznać, że Konstytucja chroni prawa nabyte w drodze dziedziczenia, nie przesądzając jednak kto w konkretnej sytuacji prawa te nabywa.

Trybunał zauważył również, że na podstawie art. 23 Konstytucji gospodarstwo rolne może być przedmiotem szczególnej regulacji prawnospadkowej, jednak regulacja ta nie może naruszać treści art. 21 Konstytucji, a więc także prawa do dziedziczenia. Zdaniem trybunału oznacza to, że rodzinny charakter gospodarstwa rolnego nie uzasadnia wprowadzenia innego mechanizmu przejścia własności w przypadku śmierci właściciela niż dziedziczenie. Zdaniem Trybunału nie wyklucza to jednak, że ustawodawca, odwołując się do koncepcji rodzinnego gospodarstwa rolnego jako wartości konstytucyjnej, ureguluje je w sposób szczególny. Wprawdzie art. 23 zd. 2 Konstytucji wyraża zakaz eliminacji instytucji dziedziczenia lub wprowadzenia rozwiązań, które wykluczałyby swobodę testowania lub równą ochronę praw wszystkich spadkobierców, jednocześnie jednak nie wyłącza on możliwości wprowadzenia, odnośnie do dziedziczenia gospodarstw rolnych, szczególnej regulacji modyfikującej w określonych punktach ogólne przepisy prawa spadkowego. Modyfikacje te nie mogą być jednak dowolne, ale mają służyć realizacji zasady wyrażonej w art. 23 Konstytucji, zgodnie z którą podstawą ustroju rolnego państwa jest gospodarstwo rodzinne ${ }^{30}$.

W obszernym uzasadnieniu wyroku z dnia 31 stycznia 2001 roku Trybunał Konstytucyjny przeprowadził także szczegółową analizę poszczególnych przepisów kodeksu cywilnego konstytuujących szczególny reżim dziedziczenia gospodarstw rolnych, nie wszystkie z nich uznając za sprzeczne z ustawą zasadniczą.

W pierwszej kolejności trybunał odniósł się do kluczowego z punktu widzenia omawianej problematyki art. 1058 kc., uznając, że przepis ten nie narusza Konstytucji. Zdaniem trybunału, komentowany przepis zawiera normę kolizyjną, regulująca stosunek przepisów szczególnych ujętych w tytule X Księgi IV Kodeksu cywilnego do ogólnych przepisów prawa spadkowego zamieszczonych w tytułach od I do IX tej księgi. Konstytucyjność art. 1058 kc., zdaniem trybunału, wynika z omówionego powyżej zakresu swobody przysługującej ustawodawcy przy regulacji kwestii prawa spadkowego, zaś taka odrębność mieści się w założeniu odrębności dotyczącej go-

$30 \mathrm{~W}$ dalszych rozważaniach poczynionych na gruncie art. $64 \mathrm{w}$ związku z art. 32 Konstytucji, trybunał wyjaśnił, że równej ochrony praw majątkowych nie można utożsamiać z równością praw nabywanych w drodze dziedziczenia, zaś sytuacja prawna poszczególnych spadkobierców może zostać zróżnicowana na mocy przepisów ustawowych, jeżeli jest to niezbędne dla realizacji innej wartości konstytucyjnej. 
spodarstw rolnych. Natomiast konstytucyjne przepisy uznające za podstawę ustroju rolnego gospodarstwo rodzinne otwierają możliwość dla specjalnej ingerencji ustawodawcy do kształtowania szczególnego reżimu prawnego gospodarstwa rolnego także w zakresie prawa spadkowego.

Oceniając konstytucyjność art. 1059, 1060 i 1062 kc. trybunał wskazał, że treść wymienionych przepisów tworzyła odrębny od zasad ogólnych krąg dziedziczenia spadkobierców nabywających gospodarstwo rolne i spadkobierców nabywających pozostałą część spadku. Samo wyznaczenie różnych kręgów spadkobierców nie jest naruszeniem Konstytucji, trybunał uznał jednakże, że regulacja przyjęta w ww. przepisach kc. była niezgodna $\mathrm{z}$ art. 64 Konstytucji. Zwrócono przede wszystkim uwagę na „rażąco nierówne traktowanie” spadkobierców, zarówno w grupie dziedziczącej na mocy ustawy, jak i spadkobierców ustawowych w stosunku do spadkobierców testamentowych. Ponadto, w ocenie trybunału, art. 1059, 1060 i 1062 kc. (w ówczesnym brzmieniu) nie prowadziły do realizacji celu, który miałby uzasadnienie konstytucyjne, tj. do zapewnienia gospodarstwu rolnemu określonej wielkości, co więcej, dopuszczenie do dziedziczenia ustawowego gospodarstwa rolnego wyłącznie osób określonych w art. 1059 pkt 3 kc. mogłoby uniemożliwić osiągnięcie tego celu. Ponadto, wyeliminowanie danego spadkobiercy ustawowego z kręgu osób dziedziczących gospodarstwo rolne z powodu niespełnienia żadnego z warunków opisanych w art. 1059 kc. wyłączało go z możliwości otrzymania tego gospodarstwa w wyniku działu spadku, nawet gdyby w okresie między otwarciem spadku a jego działem spełnił warunki określone w art. 1059 kc. Jak zwrócił również uwagę trybunał, przyjęta w kwestionowanych przepisach regulacja pozbawiała równej ochrony spadkobierców dziedziczących z ustawy na zasadach ogólnych, gdyż podział majątku spadkowego na gospodarstwo rolne i inne składniki już na etapie nabycia spadku prowadził do nierównego traktowania pod względem majątkowym obu grup spadkobierców, brak było bowiem mechanizmu „wyrównania” korzyści majątkowych płynących z dziedziczenia. Dla uznania niekonstytucyjności tych przepisów miało także znaczenie to, że zawężenie kręgu spadkobierców ustawowych dziedziczących gospodarstwo rolne powodowało rozszerzenie kręgu przypadków, w których gospodarstwo rolne dziedziczył z mocy ustawy Skarb Państwa.

Odnosząc się z kolei do art. 1064 kc. trybunał uznał, że artykuł ten w brzmieniu ustalonym ustawą z 1990 r. był niezgodny z Konstytucją, w szczególności z jej art. 31 ust. 3. Uznając uprawnienie ustawodawcy do odrębnego od zasad ogólnych ukształtowania modelu dziedziczenia ustawowego gospodarstw rolnych, trybunał zaznaczył, że kształtowanie prawa podmiotowego powinno być dokonywane w ustawie. Niekonstytucyjność powyższego przepisu wynikała z tego, że akt rangi podustawowej (w tym wypadku rozporządzenie Rady Ministrów) ingerował w sferę wolności i praw człowieka i obywatela.

Natomiast odnośnie do art. 1087 kc. trybunał wskazał, że przepis ten jest niekonstytucyjny, z przyczyn analogicznych jak w przypadku art. 1059 kc., gdyż zawę- 
Dziedziczenie gospodarstw rolnych a zmiany w ustawie o kształtowaniu ustroju...

żenie kręgu spadkobierców ustawowych nie jest połączone z mechanizmem równej ochrony ich praw na etapie podziału poszczególnych składników masy spadkowej. Zatem osoby wskazane w art. 1087 kc. stają się w sposób nieusprawiedliwiony uprzywilejowane w stosunku do innych spadkobierców.

Jak dalej argumentował trybunał, stwierdzenie, że treść kilku z zakwestionowanych w sprawie przepisów jest niezgodna z Konstytucją, aktualizowało konieczność rozstrzygnięcia, czy ustalenie to może spowodować uchylenie skutków materialnoprawnych wywołanych przez niezgodne z Konstytucją przepisy w okresie poprzedzającym wejście w życie omawianego wyroku. W efekcie przeprowadzonej analizy trybunał uznał, że stwierdzenie niekonstytucyjności art. 1059, 1060, 1062, 1064 kc. odnosi się jedynie do spraw spadkowych dotyczących spadków otwartych po dniu ogłoszenia omawianego wyroku trybunału. Przyjęte rozwiązanie wyłączyło możliwość ponownego orzekania w sprawie zakończonej postanowieniem o stwierdzeniu nabycia spadku, jak też możliwość niezastosowania przepisów obowiązujących w dniu otwarcia spadku, nawet jeżeli postępowanie w danej sprawie spadkowej będzie się toczyło po ogłoszeniu przedmiotowego wyroku. Natomiast odnośnie do czasowego obowiązywania art. 1063 kc., który zdaniem trybunału w brzmieniu obowiązującym od wejścia w życie ustawy zmieniającej z 1982 r. narusza art. 21 ust. 1 oraz art. 64 Konstytucji, trybunał wskazał, że sprzeczność z Konstytucją tego przepisu jest tak jednoznaczna, iż uzasadnione jest spowodowanie utraty mocy obowiązującej tego przepisu w pełnym zakresie. Regulacja ta dotyka bowiem samej istoty prawa dziedziczenia, gdyż sytuacja, w której majątek pozostały po spadkodawcy dziedziczą osoby fizyczne, a tylko należące do spadku gospodarstwo rolne Skarb Państwa, jest rażąco sprzeczna z podstawową konstytucyjną funkcją prawa dziedziczenia. Natomiast zasady ochrony praw nabytych oraz bezpieczeństwa i pewności prawa chronią jednostki i inne podmioty stosunków prawnych przed ingerencją władzy państwowej, jednakże nie dotyczą w takim samym zakresie Skarbu Państwa. Dziedziczenie Skarbu Państwa nie jest objęte konstytucyjną gwarancją prawa dziedziczenia, prawo to bowiem dotyczy przede wszystkim osób fizycznych oraz innych podmiotów prawa prywatnego. Państwo jest w tym wypadku podmiotem zobowiązanym do zapewnienia ochrony, a nie uprawnionym do korzystania z niej.

Znamiennym skutkiem omawianego wyroku było zniesienie odrębności zasad ustawowego dziedziczenia gospodarstw rolnych, to znaczy, że od momentu wejścia w życie ww. wyroku, spadkobiercy gospodarstwa rolnego określani są w myśl ogólnych zasad dziedziczenia. Natomiast art. 1058 kc. pozostał artykułem, który umożliwiał odrębną regulację porządku spadkobrania, jednak jak wielokrotnie podkreślał trybunał w uzasadnieniu ww. wyroku, regulacja taka może mieć jedynie rację bytu w przypadku spełniania przez ustawodawcę przesłanek szczegółowo określonych i opisanych w ww. wyroku' ${ }^{31}$.

31 A. Lichorowicz, Szczególny porządek..., op. cit., s. 93. 
Reasumując, wyrok Trybunału Konstytucyjnego z dnia 31 stycznia 2001 r. zamyka pewien etap rozwoju szczególnego porządku dziedziczenia gospodarstw rolnych ${ }^{32}$. Dotychczasowy porządek prawny dziedziczenia gospodarstwa rolnego, w odniesieniu do spadków otwartych po 14 lutego 2001 r. został uchylony, natomiast zakres stosowania nieuchylonych przez trybunał przepisów został ograniczony tak dalece, że de facto stały się normami pustymi (z wyjątkiem art. 1067 i 1081 kc.). Podkreślić również należy, że swoją aktualność zachowały przepisy art. 213-217 kc. określające zasady działania gospodarstwa rolnego wchodzącego w skład spadku.

Na mocy cytowanego powyżej wyroku Trybunału Konstytucyjnego, poczynając od 14 lutego 2001 r. nie obowiązywały w Polsce ograniczenia w dziedziczeniu gospodarstw rolnych. Ustawodawca zdecydował się na wprowadzenie tego rodzaju ograniczeń dopiero od 30 kwietnia 2016 r., poprzez nowelizację ustawy o kształtowaniu ustroju rolnego ${ }^{33}$. Warto zwrócić uwagę na wnioski płynące z ww. wyroku trybunału, mianowicie - ustawodawca ma znaczny zakres swobody, jeżeli chodzi o ukształtowanie prawa spadkowego w przypadku gospodarstw rolnych, jeśli tylko jego działanie nie dopuszcza do „ukrytego wywłaszczenia” i dostosowuje porządek prawny do przypuszczalnej woli spadkodawcy. Oczywiście takie działanie ustawodawcy musi realizować także inne wartości konstytucyjne ${ }^{34}$.

\section{Kwestia dziedziczenia gospodarstw rolnych w świetle ustawy o kształtowaniu ustroju rolnego}

Jak wynika z art. 23 Konstytucji, gospodarstwa rolne, będące gospodarstwami rodzinnymi, stanowią podstawę ustroju rolnego państwa i podlegają szczególnej regulacji w ustawie $z$ dnia 11 kwietnia 2003 r. o kształtowaniu ustroju rolnego.

Praktycznie od chwili wejścia w życie ustawa ta wywoływała kontrowersje merytoryczne w zakresie realizacji określonych w niej celów, tj. jeśli chodzi o poprawę struktury obszarowej gospodarstw rolnych, przeciwdziałanie nadmiernej koncentracji nieruchomości rolnych oraz zapewnienie prowadzenia działalności rolniczej w gospodarstwach rolnych przez osoby o odpowiednich kwalifikacjach ${ }^{35}$.

Zmiana wskazanej ustawy dokonana na podstawie ustawy z dnia 14 kwietnia 2016 r. o wstrzymaniu sprzedaży nieruchomości Zasobu Własności Rolnej Skarbu Państwa oraz o zmianie niektórych ustaw, zgodnie z deklaracjami ustawodawcy ma

32 Ibidem.

33 J. Bieluk, Nowe zasady dziedziczenia gospodarstw rolnych po nowelizacji ustawy o kształtowaniu ustroju rolnego, „Studia Iuridica Agraria” 2016, t. XIV, s. 75-77.

34 A. Lichorowicz, Szczególny porządek..., op. cit., s. 94-104.

35 J. Mikołajczyk, Problematyka obrotu nieruchomościami rolnymi w świetle projektowanych zmian ustawy o ukształtowaniu ustroju rolnego, referat wygłoszony na X Krajowej Konferencji Rynku Nieruchomości, 22 stycznia 2016 r., http://pprn.pl/?p=19420 (data dostępu: 7.09.2017 r.). 
Dziedziczenie gospodarstw rolnych a zmiany w ustawie o kształtowaniu ustroju...

zmierzać do wzmocnienia ochrony ziemi rolniczej w Polsce przed jej spekulacyjnym wykupywaniem przez osoby krajowe i zagraniczne, niegwarantujące zgodnego $\mathrm{z}$ interesem społecznym wykorzystania nabytej ziemi na cele rolnicze. Ustawodawca wyszedł bowiem z założenia, że dotychczasowe przepisy w połączeniu z przepisami prawa europejskiego nie stanowią dostatecznej gwarancji w tym zakresie ${ }^{36}$. Zmiany w komentowanej ustawie argumentowane były obawą przed wykupem polskiej ziemi rolnej przez obywateli innych krajów unijnych, szczególnie tych, w których istnieją wyższe ceny tych nieruchomości oraz bariery prawne nabycia takich gruntów przez cudzoziemców, jak i własnych obywateli niebędących rolnikami, zwłaszcza że jak dostrzegł ustawodawca, w związku z ograniczonym zasobem ziemi uprawnej, inwestycja w grunty rolne stanowić może korzystną lokatę kapitału ${ }^{37}$.

W ramach wspomnianej nowelizacji został rozszerzony, sformułowany w art. 2 ww. ustawy, słownik definicji ustawowych. Przede wszystkim należy zaznaczyć, że definiując pojęcie nabycia nieruchomości rolnej ustawodawca wskazał, iż jego zakres obejmuje każde zdarzenie prawne łącznie z obrotem mortis causa, a także ze zdarzeniami powodującymi nabycie nieruchomości wskutek upływu czasu (zasiedzenie). Co równie istotne $\mathrm{z}$ punktu widzenia analizowanej problematyki, ustawodawca, nowelizując ustawę o kształtowaniu ustroju rolnego rozstrzygnął, że poza wyjątkami wskazanymi w ustawie, nieruchomość rolną może nabyć tylko rolnik indywidualny ${ }^{38}$. Regulacja taka w zasadzie eliminuje z obrotu jako nabywców nieruchomości rolnych wszystkie inne podmioty oprócz rolnika indywidualnego. Zakresem regulacji ustawy o kształtowaniu ustroju rolnego objęto zatem także dziedziczenie gospodarstw rolnych. Od tej bardzo rygorystycznej regulacji ustawodawca przewidział jednak pewne wyjątki.

I tak, zgodnie $z$ art. 2a ust. 3 pkt 1 u.k.u.r., oprócz rolnika indywidualnego, nieruchomość rolną może nabyć również osoba bliska zbywcy, jednostka samorządu terytorialnego i Skarb Państwa lub działająca na jego rzecz Agencję Nieruchomości Rolnych (obecnie Krajowy Ośrodek Wsparcia Rolnictwa - KOWR), a także tzw. wyznaniowa osoba prawna. Ponadto, możliwe jest nabycie nieruchomości rolnej na mocy decyzji administracyjnej wydanej przez Prezesa KOWR, która może zostać wydana na wniosek zbywcy, po spełnieniu określonych warunków, oraz w związku z zamierzeniem utworzenia gospodarstwa rodzinnego przez osobę fizyczną (art. 2a ust. 4 pkt 2 u.k.u.r.), która również musi jednak spełniać określone w ustawie przesłanki ${ }^{39}$.

36 H. Ciepła, Aspekty prawne obrotu gruntami rolnymi od 30 kwietnia 2016 r. na nowych zasadach ustalonych w ustawie z dnia 11 kwietnia 2003 r. o kształtowaniu ustroju rolnego oraz w ustawie z dnia 14 kwietnia 2016 r. o wstrzymaniu sprzedaży nieruchomości Zasobu Własności Rolnej Skarbu Państwa, „Rejent” 2016, nr 9.

37 Ibidem.

38 Ibidem, s. 56.

39 Ibidem, s. 57-90. 
Ponadto, zgodnie z art. 2a ust. 3 pkt 2 omawianej ustawy, przepis ten nie dotyczy nabycia nieruchomości rolnej, będącego wynikiem dziedziczenia oraz zapisu windykacyjnego. W świetle tego przepisu, nabywcą nieruchomości rolnej w drodze dziedziczenia zarówno testamentowego, jak i ustawowego może być osoba, która nie jest rolnikiem indywidualnym. Takie uregulowanie pozostaje w zgodzie z konstytucyjnym prawem dziedziczenia (art. 21 ust. 1 i art. 64 ust. 1 i 2 Konstytucji), bowiem nie godzi w wybór spadkodawcy, kogo może powołać do spadku, oraz w jakiej formie może to uczynić. Natomiast osoby powołane (z testamentu lub ustawy) są chronione w swym prawie nabycia własności po zmarłym ${ }^{40}$.

Należy jednak jednocześnie wskazać, że na mocy znowelizowanej ustawy o kształtowaniu ustroju rolnego na nabywcę nieruchomości rolnej nałożony został obowiązek osobistego prowadzenia gospodarstwa rolnego, w skład którego weszła nabyta nieruchomość, oraz zakaz zbywania i oddawania w posiadanie nabytej nieruchomości osobom trzecim przez okres 10 lat. Także i w tym wypadku, nabywcy nieruchomości rolnych (i gospodarstw rolnych) w drodze dziedziczenia zostali potraktowani nieco inaczej niż nabywcy w obrocie inter vivos. W myśl art. $2 \mathrm{~b}$ ust. 4 znowelizowanej u.k.u.r., do nabywców nieruchomości rolnej określonych w art. 2a ust. 3 pkt 2 i 3 u.k.u.r. nie stosuje się przepisów art. 2 b ust. 1 i 2 tej ustawy, przez co spadkobierca nieruchomości rolnej, jak również zapisobiorca windykacyjny nie mają obowiązku prowadzenia gospodarstwa rolnego, w skład którego weszłaby nabyta nieruchomość rolna, przez wskazany co najmniej 10-letni okres po jej nabyciu. Nieruchomość rolna nabyta w ten sposób może być także zbyta lub oddana innym podmiotom w posiadanie.

Co warto jednak podkreślić, wskazane regulacje nie obejmują nabycia nieruchomości rolnej (gospodarstwa rolnego) w wyniku wykonania zapisu zwykłego. Może to dziwić, bowiem brak jest jakiegokolwiek uzasadnienia dla różnicowania sytuacji prawnej nabywców nieruchomości rolnych w drodze następstwa mortis causa według kryterium technicznoprawnego sposobu przejścia praw należących do zmarłego na nabywcę. Obecny zakres zastosowania wskazanych przepisów powoduje, że spadkodawca może bez ograniczeń przeznaczyć nieruchomość rolną dowolnej osobie, jednakże dla skuteczności powołania musi wybrać bądź powołanie tej osoby do dziedziczenia, bądź wskazać tę osobę jako beneficjenta zapisu windykacyjnego. W przypadku wyboru np. zapisu zwykłego, nabycie nieruchomości będzie podlegało wymogom stawianym przez art. 2a i 2b u.k.u.r., czego konsekwencją jest preferencyjne traktowanie osób bliskich spadkobiercy. Wynika to stąd, że zapisobierca, aby móc dziedziczyć gospodarstwo rolne, w skład którego wchodzi przecież nieruchomość rolna, o ile nie jest osobą bliską zbywcy, musi być rolnikiem indywidualnym.

40 P. Księżak, Nabycie nieruchomości rolnej wskutek sukcesji mortis causa w świetle przepisów ustawy o kształtowaniu ustroju rolnego, (w:) P. Księżak, J. Mikołajczyk (red.), Nieruchomości rolne w praktyce notarialnej, Warszawa 2017, s. 148-149. 
Dziedziczenie gospodarstw rolnych a zmiany w ustawie o kształtowaniu ustroju...

Jeżeli zapisobiorca zwykły nie jest rolnikiem indywidualnym, ani osobą bliską spadkobiercy, wykonanie zapisu zwykłego może nastąpić jedynie na zasadach określonych w art. 2a ust. 3 omawianej ustawy, tj. za zgodą Prezesa KOWR wyrażoną w formie decyzji administracyjnej. Oznacza to, że wola spadkodawcy, obejmująca wskazanie nabywcy gospodarstwa rolnego, w przypadku zapisu zwykłego nie ma znaczenia (odmiennie niż w przypadku zapisu windykacyjnego $)^{41}$.

W literaturze zauważa się ponadto, że wykładnia testamentu bywa niejednoznaczna i niektóre postanowienia mogą być zarówno zakwalifikowane jako powołanie do spadku, jak i zapis zwykły, co w znaczący sposób rzutuje na sytuację prawną spadkobiercy. Tymczasem ta różnica nie jest odzwierciedlona w przepisach dotyczących gospodarstw rolnych. Na status prawny spadkobiercy wpływa bowiem kwestia zupełnie przypadkowa, a mianowicie przedmioty, które znajdują się w majątku spadkowym oprócz gospodarstwa rolnego. Jeśli nieruchomość ta wyczerpuje prawie cały spadek, spadkobierca może być powołany do spadku i być w korzystniejszej - pod względem prawnorolnym - sytuacji, niż jeśli spadkodawca posiadał większy majątek, a uprawniony jest wtedy traktowany jak zapisobierca ${ }^{42}$.

Kolejnym wprowadzonym do u.k.u.r. przepisem jest art. 2c, zgodnie z którym przepisy tej ustawy dotyczące nabycia nieruchomości rolnej (także w zakresie dziedziczenia) stosuje się odpowiednio do nabycia udziału lub części udziału we współwłasności nieruchomości rolnej.

Śledząc kolejne regulacje omawianej ustawy z punktu widzenia sytuacji prawnej nabywców nieruchomości rolnych w wyniku dziedziczenia, należy odnieść się również do zagadnienia prawa pierwokupu oraz prawa wykupu. Zgodnie z art. 3 ust. 1 u.k.u.r., w przypadku sprzedaży nieruchomości rolnej prawo pierwokupu przysługuje z mocy ustawy dzierżawcy, jeżeli umowa dzierżawy została zawarta w formie pisemnej i ma datę pewną oraz była wykonywana co najmniej przez 3 lata, licząc od tej daty, oraz nabywana nieruchomość rolna wchodzi w skład gospodarstwa rodzinnego dzierżawcy. Regulacje dotyczące pierwokupu dzierżawcy nie zostały znowelizowane, natomiast zmiany objęły prawo pierwokupu przysługujące KOWR w przypadku braku uprawnionego dzierżawcy lub nieskorzystania przez niego z przysługującego mu prawa. Prawo pierwokupu przysługuje KOWR bez względu na powierzchnię nieruchomości rolnej, również w zakresie prawa wieczystego użytkowania, jest ono natomiast wyłączone w przypadku, gdy kupującym jest osoba bliska sprzedającego, jednostka samorządu terytorialnego, Skarb Państwa oraz jeśli sprzedaż dokonywana jest między osobami prawnymi tego samego kościoła lub związku wyznaniowego (art. 3 ust. 5 pkt 3 u.k.u.r.). Odnośnie prawa wykupu nieruchomości rolnej zauważyć należy, iż obecnie uprawnienie to może dotyczyć każdego zdarzenia prawnego - rów-

\footnotetext{
41 Ibidem, s. 148-152.

42 Ibidem, s. 150.
} 
nież nabycia w drodze dziedziczenia, zapisu windykacyjnego, zasiedzenia, podziału, przekształcenia lub łączenia spółek ${ }^{43}$.

Zgodnie z art. 4 ust. 1 pkt 4 lit. a u.k.u.r., jeżeli nabycie nieruchomości rolnej następuje $\mathrm{w}$ wyniku dziedziczenia lub zapisu windykacyjnego, którego przedmiotem jest nieruchomość rolna lub gospodarstwo rolne, KOWR działający na rzecz Skarbu Państwa może złożyć oświadczenie o nabyciu nieruchomości za zapłatą równowartości pieniężnej odpowiadającej wartości rynkowej nabywanej nieruchomości. Uprawnienie to nie przysługuje jednak, gdy nabycie nieruchomości rolnej następuje $\mathrm{w}$ wyniku dziedziczenia ustawowego albo dziedziczenia przez rolnika indywidualnego (art. 4 ust. 4 pkt 2 lit. c u.k.u.r.) albo przez rolnika indywidualnego w wyniku zapisu windykacyjnego (art. 4 ust. 4 pkt 2 lit. d u.k.u.r.). Uprawnienie takie nie przysługuje również w przypadku, gdy nabycie następuje między osobami bliskimi (art. 4 ust. 4 pkt 2 lit. b u.k.u.r.), niezależnie od tytułu nabycia. W związku z tym, stosowanie prawa nabycia w związku z sukcesją po zmarłym kształtuje się następująco: prawo nabycia nie przysługuje nigdy w wypadku dziedziczenia ustawowego, nie przysługuje ono także w wypadku dziedziczenia testamentowego przez osobę, która nie jest rolnikiem indywidualnym i jednocześnie nie jest osobą bliską spadkodawcy, natomiast prawo nabycia przysługuje $\mathrm{w}$ wypadku nabycia $\mathrm{w}$ drodze zapisu windykacyjnego przez osobę niebędącą rolnikiem indywidualnym i zarazem niebędącą osobą bliską spadkodawcy. Wynika to z faktu, że krąg spadkobierców ustawowych nie pokrywa się z kręgiem osób bliskich zdefiniowanym w znowelizowanej ustawie ${ }^{44}$.

Warto także zaznaczyć, że zgodnie z art. 4 ust. 5 pkt 1 lit. c u.k.u.r., do wykonywania prawa nabycia stosuje się odpowiednio przepisy art. 3 ust. 10 i 11 oraz przepisy kc. dotyczące prawa pierwokupu ${ }^{45}$.

Innym istotnym zagadnieniem wynikłym na tle stosowania znowelizowanej ustawy o kształtowaniu ustroju rolnego w zakresie nabywania nieruchomości rolnych w drodze dziedziczenia jest kwestia zakresu stosowania art. 9 u.k.u.r. Jak wiadomo, przepis ten określa przypadki, w których naruszenie przepisów ustawy skutkuje nieważnością nabycia nieruchomości rolnej. W szczególności poważne wątpliwości budzi rozwiązanie, zgodnie z którym w razie naruszenia pewnych obowiązków przez nabywcę nieruchomości rolnej może dojść do stwierdzenia nabycia przez sąd własności nieruchomości przez KOWR ${ }^{46}$. Jako słuszny wskazać w tym miejscu należy pogląd, że art. 9 u.k.u.r. nie ma zastosowania do nabywania nieruchomości rolnych w drodze dziedziczenia lub zapisu windykacyjnego, gdyż w tych wypadkach nabycie

43 K. Maj, Zmiany w ustawie o kształtowaniu ustroju rolnego obowiązujące od dnia 30 kwietnia 2016 r., „Krakowski Przegląd Notarialny” 2016, nr 2, s. 90-93.

44 P. Księżak, Nabycie nieruchomości..., op. cit., s. 155-156.

45 Ibidem, s. 157.

46 K. Maj, Zmiany w ustawie o kształtowaniu..., op. cit., s. 93-101. 
Dziedziczenie gospodarstw rolnych a zmiany w ustawie o kształtowaniu ustroju...

następuje ex lege, a w konsekwencji spadkodawca nie musi dopełniać żadnych formalności, aby doszło do nabycia nieruchomości rolnej ${ }^{47}$.

Odnosząc się do przepisów przejściowych i końcowych regulujących wejście w życie omawianej nowelizacji ustawy o kształtowaniu ustroju rolnego, zwrócić należy uwagę na art. 11 ustawy z dnia 14 kwietnia 2016 r. o wstrzymaniu sprzedaży nieruchomości Zasobu Własności Rolnej Skarbu Państwa oraz o zmianie niektórych ustaw. Przepis ten wprowadza generalne wyłączenie stosowania ustawy o kształtowaniu ustroju rolnego w brzmieniu ustalonym omawianą nowelizacją w stosunku do dwóch kategorii nieruchomości.

Pierwsza z nich obejmuje zbiór nieruchomości będących gruntami rolnymi zabudowanymi o powierzchni nieprzekraczającej 0,5 ha, które w dniu 30 kwietnia 2016 r. zajęte są pod budynki mieszkalne oraz budynki, budowle i urządzenia niewykorzystane obecnie do produkcji rolniczej, wraz z gruntami do nich przyległymi umożliwiającymi ich właściwe wykorzystanie oraz zajętymi na urządzenie ogródka przydomowego - jeżeli grunty te tworzą zorganizowaną całość gospodarczą oraz nie zostały wyłączone z produkcji rolnej w rozumieniu ustawy z dnia 3 lutego 1995 r. o ochronie gruntów rolnych i leśnych.

Kolejną kategorią są nieruchomości rolne, które w dniu 30 kwietnia 2016 r. w ostatecznych decyzjach o warunkach zabudowy i zagospodarowania terenu przeznaczone są na cele inne niż rolne. Z kolei art. 12 ustawy nowelizującej nakazuje stosować przepisy dotychczasowe do postępowań dotyczących nabycia nieruchomości rolnych oraz wpisu do księgi wieczystej m.in. na podstawie ustawy o kształtowaniu ustroju rolnego ${ }^{48}$. Konsekwentnie należy uznać, że wyłączenia te mają zastosowanie do nabywania w drodze dziedziczenia i obejmują także nabywców na podstawie zapisu zwykłego.

\section{Podsumowanie}

Reasumując należy wyrazić pogląd, że kwestia spójnego i adekwatnego do potrzeb systemu norm oddziaływujących na obrót nieruchomościami rolnymi i gospodarstwami rolnymi w procesie dziedziczenia nadal pozostaje otwarta. Najwyraźniej zagadnienie to nie ma szczęścia do trafnej i spójnej regulacji. Do 1989 r. reglamentacja w tym zakresie była podyktowana przede wszystkim założeniami politycznymi panującego wówczas systemu polityczno-gospodarczego. Również głęboka liberalizacja rozwiązań normatywnych w tym zakresie, do której doszło w wyniku przemian społeczno-gospodarczych przełomu lat 80. i 90. ubiegłego wieku, niewątpliwie nie była przemyślana, co jasno stwierdził Trybunał Konstytucyjny w wyroku z dnia 31 stycznia 2001 roku. Co warto zaznaczyć, w obszernym uzasadnieniu tego wyroku

47 P. Księżak, Nabycie nieruchomości..., op. cit., s. 157.

48 Ibidem, s. 101-104. 
trybunał wskazał na szerokie ramy prawne, w których możliwe, a nawet zasadne, jest uregulowanie odrębnych zasad dziedziczenia gospodarstw rolnych.

Zestawienie wielu trafnych poglądów i opinii wyrażonych przez trybunał z regulacją kwestii dziedziczenia gospodarstw rolnych, wprowadzoną na mocy ostatniej nowelizacji ustawy o kształtowaniu ustroju rolnego musi rozczarowywać. Nie dość, że współczesna regulacja nie obejmuje gospodarstw rolnych - także rodzinnych skuteczną i efektywną ochroną w procesie dziedziczenia, to dodatkowo, wskutek braku precyzji przyjętych rozwiązań potęguje niepewność co do rzeczywistej sytuacji prawnej nabywców. O ile obrót ziemią rolną inter vivos jest ściśle regulowany (choć i tu szereg rozwiązań jest dalekich od precyzji), to na tym tle zagadnienia związane z dziedziczeniem gospodarstw rolnych wydają się być regulowane przypadkowo, niejako „przy okazji” regulowania zagadnień związanych z obrotem inter vivos. Aby osiągnąć spójność systemu prawnego, do czego ustawodawca powinien zawsze dążyć, należałoby w podobny, kompleksowy i wszechstronny sposób uregulować kwestie dziedziczenia gospodarstw rolnych. Obejmowanie obrotu nieruchomościami rolnymi szczegółową reglamentacją, bez jednoczesnego uzupełnienia tej regulacji przepisami chroniącymi gospodarstwa rolne, a zwłaszcza gospodarstwa rodzinne, w procesie dziedziczenia, wydaje się być dalece niekonsekwentne.

\section{BIBLIOGRAFIA}

Bieluk J., Nowe zasady dziedziczenia gospodarstw rolnych po nowelizacji ustawy o kształtowaniu ustroju rolnego, „Studia Iuridica Agraria” 2016, t. XIV.

Ciepła H., Aspekty prawne obrotu gruntami rolnymi od 30 kwietnia 2016 r. na nowych zasadach ustalonych w ustawie $\mathrm{z}$ dnia 11 kwietnia $2003 \mathrm{r}$. o kształtowaniu ustroju rolnego oraz w ustawie $\mathrm{z}$ dnia 14 kwietnia 2016 r. o wstrzymaniu sprzedaży nieruchomości Zasobu Własności Rolnej Skarbu Państwa, „Rejent” 2016, nr 9.

Księżak P., Nabycie nieruchomości rolnej wskutek sukcesji mortis causa w świetle przepisów ustawy o kształtowaniu ustroju rolnego, (w:) P. Księżak, J. Mikołajczyk (red.), Nieruchomości rolne w praktyce notarialnej, Warszawa 2017.

Lichorowicz A., Szczególny porządek dziedziczenia gospodarstw rolnych w Polsce po orzeczeniu Trybunału Konstytucyjnego z dnia 31 I 2001 r., „Rejent” 2001, nr 9 (125).

Lichorowicz A., Podstawowe rozwiązania regulujące status prawny gospodarstw rodzinnych w krajach Europy Zachodniej, (w:) P. Litwiniuk (red.), Prawne mechanizmy wspierania i ochrony rolnictwa rodzinnego w Polsce i innych państwach Unii Europejskiej, Warszawa 2015.

Maj K., Zmiany w ustawie o kształtowaniu ustroju rolnego obowiązujące od dnia 30 kwietnia 2016 r., „Krakowski Przegląd Notarialny” 2016, nr 2.

Mikołajczyk J., Problematyka obrotu nieruchomościami rolnymi w świetle projektowanych zmian ustawy o ukształtowaniu ustroju rolnego, referat wygłoszony na X Krajowej Konferencji Rynku Nieruchomości, 22 stycznia 2016 r., http://pprn.pl/?p=19420.

Stelmachowski A., Zdziennicki B., Prawo rolne, Warszawa 1980. 